\title{
Pemberian Tepung Daun Pepaya (Carica Papaya) Dalam Ransum Terhadap Karkas Burung Puyuh (Coturnix Coturnix Javonica)
}

\author{
Puja Soraya $^{1}$, Muharram Fajrin ${ }^{2}$, Mukhlis Hasibuan ${ }^{3}$ \\ ${ }^{1}$ Alumni Fakultas Peternakan Program Studi Peternakan Universitas Muhammadiyah \\ Tapanuli Selatan,e-mail : Pujasoraya_hrp@gmail.com \\ ${ }^{2}$ Dosen Program Studi Peternakan Fakultas Peternakan Universitas Muhammadiyah \\ Tapanuli Selatan,e-mail : muharram.fajrin@um-tapsel.ac.id \\ ${ }^{3}$ Dosen Program Studi Agroteknologi Fakultas Pertanian Universitas Muhammadiyah \\ Tapanuli Selatan,e-mail : mukhlis@um-tapsel.ac.id
}

\begin{abstract}
ABSTRAK
Penelitian ini telah dilaksanakan dikandang aneka ternak Mix Farming Exverience (MFE) Fakultas Perternakan Universitas Muhammadiyah Tapanuli Selatan, Kota Padangsidimpuan. Selama enam minggu, dimulai dari bulan Januari sampai bulan Maret 2017 diawali sejak persiapan tempat penelitian, sampai penelitian berakhir. Penelitian ini bertujuan untuk mengetahui pemberian tepung daun pepaya (Carica papaya) dalam ransum terhadap bobot hidup, bobot karkas, persentase karkas dan panjang usus burung puyuh (Coturnixcoturnix javonica).Rancangan yang digunakan adalah Rancangan Acak Lengkap (RAL) dengan jumlah perlakuan $(\mathrm{t})=4$, ulangan $(\mathrm{n})=6$. Susunan ransum R0 (tanpa penambahan tepung daun pepaya sebanyak $0 \%$ ), R1 (penambahan tepung daun pepaya sebanyak $5 \%$ ), R2 (Penambahan tepung daun pepaya sebanyak 10\%), R3 (penambahan tepung daun pepaya sebanyak 15\%). Dari hasil penelitian dapat disimpulkan, bahwa pemberian tepung daun pepaya (Carica papaya) dalam ransum tidak berpengaruh pada bobot hidup, bobot karkas, persentase karkas dan panjang usus burung puyuh. Perlakuan terbaik dari penelitian yang dilakukan terdapat pada ransum dengan penambahan tepung daun pepaya $10 \%$ terhadap persentase karkas sebesar 70,77\%.
\end{abstract}

Kata kunci : Tepung daun pepaya, burung puyuh, karkas

\section{PENDAHULUAN}

Puyuh yang biasa dibudidayakan berjenis kelamin betina untuk menghasilkan telur, sedangkan puyuh jantan yang tidak digunakan sebagai pejantan dapat dimanfaatkan sebagai sumber daging. Puyuh yang digunakan sebagai pedaging biasanya berupa puyuh jantan dan puyuh betina atau puyuh yang sudah tidak berproduksi sehingga dagingnya rendah (Rasyaf, 2005).

Puyuh yang dipanen pada umur muda akan menghasilkan mutu daging yang lebih baik dan dagingnya empuk karena perbedaan umur potong puyuh akan terkait dengan tinggi dan rendahnya bobot potong. Oleh karena itu ransum yang diberikan harus sesuai dengan kebutuhan akan proteinnya agar menghasilkan bobot hidup, bobot karkas, persentase karkas, dan panjang usus. Salah satu cara yang dilakukan untuk memenuhi kebutuhan protein dalam 
ransum dapat dilakukan dengan pemanfaatan daun pepaya sebagai pakan puyuh dengan membuatnya menjadi tepung, selain meningkatkan nilai palatabilitasnya pengolahan daun pepaya menjadi tepung juga mampu meningkatkan berat badan pada ternak.

Tanaman pepaya (Carica papaya)merupakan tanaman yang tumbuh di dataran rendah maupun daratan tinggi, banyak dijumpai di Indonesia sebagai tanaman yang kaya manfaat. Tanaman pepaya memiliki banyak manfaat mulai dari bagian akar, batang, daun, bunga dan buahnya, yaitu sebagai sumber vitamin, mineral dan senyawa lainnya untuk kebugaran tubuh dan berhasiat dalam bidang kesehatan, memperbaiki pencernaan serta menambah nafsu makan (Suryawiria, 2002) .

Ransum yang diberikan pada burung puyuh terdiri dari beberapa bentuk, yaitu pellet, remah, dan tepung. Ransum terbaik adalah yang berbentuk tepung, sebab burung puyuh yang mempunyai sifat usil dan sering mematuk karena burung puyuh akan mempunyai kesibukan lain dengan mematuk-matuk pakannya. Jumlah ransum yang diberikan kepada puyuh harus diberikan dalam jumlah yang mencukupi dan tersedia terus menerus (adlibitum).

\section{METODE PENELITIAN}

Ternak yang digunakan adalah burung puyuh umur satuhari (DOQ) sebanyak120 ekor tanpa membedakan jenis kelamin (unsexing), sampel diambil dari burung puyuh yang telah dipelihara selama enam minggu sesuai perlakuan.

\section{Variabel dan Instrumen Penelitian}

\section{Bobot hidup (gr)}

Bobot hidup adalah hasil penimbangan hewan hidup setelah dipuasakan selama 12 jam (Hardjosubroto dan Astuti, 1993).

\section{Karkas (gr)}

Merupakan daging bersama tulang hasil pemotongan setelah dipisahkan kepala sampai batas pangkal leher, kaki sampai lutut, isi rongga perut bagian dalam serta bulu dan darah.

\section{Persentase karkas $(\%)$}

Persentase karkas adalah perbandingan antara bobot karkas dengan bobot hidup dikali seratus persen (100\%).Persentase karkas merupakan faktor yang penting untuk menilai produk dari ternak daging.Secara umum persentase karkas berkisar antara 65-75\% dari berat hidup (Priyanto, 1977).

$\%$ karkas $=\underline{\text { Berat Karkasx }} 100 \%$

Bobot hidup 


\section{Panjang usus (cm)}

Panjang usus bervariasi tergantung pada kebiasaan makanan unggas, puyuh dewasa memiliki usus halus sepanjang 1 meter (Suprijatna, 2008).

\section{Bahan yang digunakan}

1, Burung puyuh yang berumur satu hari (DOQ)

2. Air minum yang diberikan secara adlibitum

3. Ransum berdasarkan perlakuan

4. Vaksin dan obat obatan

5. Desinfektan (Rhodalon)

\section{Rancangan Penelitian}

Rancangan penelitian yang digunakan adalah Rancangan Acak Lengkap (RAL) dengan jumlah perlakuan $(T)=4$ dan ulangan $(n)=6$.

Adapun susunan perlakuan ransum adalah sebagai berikut :

$\mathrm{R} 0=$ Ransum tanpa penambahan tepung daun pepaya $(0 \%)$

$\mathrm{R} 1=$ Ransum dengan penambahan tepung daun pepaya $(5 \%)$

$\mathrm{R} 2=$ Ransum dengan penambahan tepung daun pepaya $(10 \%)$

$\mathrm{R} 3=$ Ransum dengan penambahan tepung dau pepaya (15\%)

Tabel 1. Susunan ransum selama penelitian fase starter (0-3 minggu)

\begin{tabular}{lccccc}
\hline \multicolumn{1}{c}{ Bahan Pakan } & & $\mathrm{R} 0$ & $\mathrm{R} 1$ & $\mathrm{R} 2$ & $\mathrm{R} 3$ \\
\hline T. Ikan & $(\mathrm{Kg})$ & 5 & 5 & 5 & 5 \\
T.Jagung & $(\mathrm{Kg})$ & 42 & 40 & 40 & 40 \\
Bungkil Kedelai & $(\mathrm{Kg})$ & 30 & 29 & 29 & 29 \\
Dedak & $(\mathrm{Kg})$ & 22 & 20 & 15 & 10 \\
T.Daun Pepaya & $(\mathrm{Kg})$ & 0 & 5 & 10 & 15 \\
Mineral & $(\mathrm{Kg})$ & 1 & 1 & 1 & 1 \\
\hline Jumlah & & 100 & 100 & 100 & 100 \\
\hline EM & $(\%)$ & 2804,41 & 2672,25 & 2591,91 & 2511,59 \\
Protein Kasar & $(\%)$ & 22,89 & 22,13 & 21,60 & 21,08 \\
Serat Kasar & $(\%)$ & 5,34 & 5,02 & 4,40 & 3,79 \\
Kalsium & $(\%)$ & 0,60 & 0,61 & 0,61 & 0,62 \\
Posfor & $(\%)$ & 0,50 & 0,51 & 0,53 & 0,55 \\
Lemak Kasar & $(\%)$ & 6,00 & 5,66 & 5,03 & 4,41 \\
\hline
\end{tabular}

Tabel. 2. Susunan ransum selama penelitian fase Grower (3-5 minggu)

\begin{tabular}{lccccc}
\hline \multicolumn{1}{c}{ Bahan Pakan } & & R0 & R1 & R2 & R3 \\
\hline T. Ikan & $(\mathrm{Kg})$ & 5 & 5 & 5 & 5 \\
T.Jagung & $(\mathrm{Kg})$ & 40 & 38 & 36 & 34 \\
Bungkil Kedelai & $(\mathrm{Kg})$ & 32 & 30 & 28 & 26 \\
Dedak & $(\mathrm{Kg})$ & 22 & 21 & 20 & 19
\end{tabular}


| JURNAL PETERNAKAN | VOLUME : 03 | NO : 01 | TAHUN 2019 | E-ISSN. 2599-1736| 32

\begin{tabular}{lccccc}
\hline T.Daun Pepaya & $(\mathrm{Kg})$ & 0 & 5 & 10 & 15 \\
Mineral & $(\mathrm{Kg})$ & 1 & 1 & 1 & 1 \\
\hline Jumlah & & 100 & 100 & 100 & 100 \\
\hline EM & $(\%)$ & 2770,85 & 2632,57 & 2494,29 & 2356,01 \\
Protein Kasar & $(\%)$ & 23,61 & 22,53 & 21,44 & 20,36 \\
Serat Kasar & $(\%)$ & 5,40 & 5,16 & 4,92 & 4,68 \\
Kalsium & $(\%)$ & 0,62 & 0,61 & 0,61 & 0,61 \\
Posfor & $(\%)$ & 0,51 & 0,52 & 0,53 & 0,54 \\
Lemak Kasar & $(\%)$ & 6,62 & 5,76 & 5,50 & 5,25 \\
\hline
\end{tabular}

Tabel. 3. Susunan ransum selama penelitian fase Finisher( $>5$ minggu)

\begin{tabular}{lccccc}
\hline \multicolumn{1}{c}{ Bahan Pakan } & & $\mathrm{R} 0$ & $\mathrm{R} 1$ & $\mathrm{R} 2$ & $\mathrm{R} 3$ \\
\hline T. Ikan & $(\mathrm{Kg})$ & 5 & 5 & 5 & 5 \\
T.Jagung & $(\mathrm{Kg})$ & 42 & 40 & 38 & 36 \\
Bungkil Kedelai & $(\mathrm{Kg})$ & 32 & 31 & 30 & 29 \\
Dedak & $(\mathrm{Kg})$ & 20 & 18 & 16 & 14 \\
T.Daun Pepaya & $(\mathrm{Kg})$ & 0 & 5 & 10 & 15 \\
Mineral & $(\mathrm{Kg})$ & 1 & 1 & 1 & 1 \\
\hline Jumlah & & 100 & 100 & 100 & 100 \\
\hline EM & $(\%)$ & 2816,61 & 2681,43 & 2552,25 & 2420,07 \\
Protein Kasar & $(\%)$ & 23,53 & 22,77 & 22,0 & 21,24 \\
Serat Kasar & $(\%)$ & 5,18 & 4,86 & 4,55 & 4,23 \\
Kalsium & $(\%)$ & 0,61 & 0,62 & 0,62 & 0,62 \\
Posfor & $(\%)$ & 0,51 & 0,52 & 0,54 & 0,55 \\
Lemak Kasar & $(\%)$ & 5,83 & 5,48 & 5,13 & 4,79 \\
\hline
\end{tabular}

\section{HASIL DAN PEMBAHASAN}

\section{Pengaruh Perlakuan Terhadap Bobot Hidup Burung Puyuh}

Bobot hidup burung puyuh adalah berat badan akhir sebelum disembelih. Bobot hidup (g/ekor) diperoleh dengan cara menimbang puyuh pada umur enam minggu ketika dipanen.

Berikut rataan bobot hidup burung puyuh pada masing masing perlakuan dapat dilihat pada dibawah ini :

Tabel 4. Rataan bobot hidup burung puyuh pada masing masing perlakuan

\begin{tabular}{|c|c|c|c|c|c|c|}
\hline \multirow{2}{*}{ Ulangan } & \multicolumn{4}{|c|}{ Perlakuan } & \multirow{2}{*}{ Total } & \multirow{2}{*}{ Rataan } \\
\hline & R0 & $\mathrm{R} 1$ & R2 & R3 & & \\
\hline 1 & 88,00 & 99,00 & 99,00 & 78,00 & 364,00 & 91,00 \\
\hline 2 & 56,00 & 82,00 & 96,00 & 97,00 & 331,00 & 82,75 \\
\hline 3 & 82,00 & 76,00 & 92,00 & 104,00 & 354,00 & 88,50 \\
\hline 4 & 96,00 & 79,00 & 74,00 & 94,00 & 343,00 & 85,75 \\
\hline 5 & 86,00 & 83,00 & 97,00 & 93,00 & 359,00 & 89,75 \\
\hline 6 & 87,00 & 75,00 & 53,00 & 97,00 & 312,00 & 78,00 \\
\hline Total & 495,00 & 494,00 & 511,00 & 563,00 & 2063,00 & 515,75 \\
\hline Rataan & 82,50 & 82,33 & 85,17 & 93,83 & 343,83 & 85,96 \\
\hline
\end{tabular}


Hasil penelitian pada Tabel 4 bahwa bobot hidup burung puyuh berkisar antara 53 gram sampai 104 gram, dengan rataan bobot hidup 85,96 gram. Bobot rataan yang tertinggi ada pada perlakuan R3 (ransum dengan penambahan tepung daun pepaya sebanyak 15\%) dengan rataan bobot hidup 93,83 gram, sedangkan yang terendah ada pada perlakuan R1 (ransum dengan penambahan tepung daun pepaya sebanyak $5 \%$ ) dengan rataan bobot hidup 82,33 gram.

Untuk mengetahui pengaruh perlakuan terhadap bobot hidup tersebut dilakukan analisis sidik ragam seperti pada Tabel 5.

Tabel 5. Hasil analisis sidik ragam pengaruh perlakuan terhadap bobot hidup burung puyuh

\begin{tabular}{|c|c|c|c|c|c|c|}
\hline \multirow{2}{*}{ SK } & \multirow{2}{*}{$\mathrm{Db}$} & \multirow{2}{*}{$\mathrm{JK}$} & \multirow{2}{*}{ KT } & \multirow{2}{*}{$\mathrm{F}_{\text {hit }}$} & \multicolumn{2}{|c|}{ F tabel } \\
\hline & & & & & $\overline{0,05}$ & 0,01 \\
\hline Perlakuan & 3 & 526,4583 & 175,4861 & $1,04^{\mathrm{tn}}$ & 3,1 & 4,94 \\
\hline Galat & 20 & 3360,5 & 168,025 & & & \\
\hline Total & 23 & 3886,958 & & & & \\
\hline
\end{tabular}

Keterangan : $\mathrm{KK}=15,0796 \%$

tn $=$ Tidak nyata

Hasil analisis sidik ragam pada Tabel 5 menunjukkan bahwa, pemberian tepung daun pepaya sampai $15 \%$ tidak berpengaruh nyata $(\mathrm{P}>0,05)$ terhadap bobot hidup. Hal ini disebabkan karena pola pertumbuhan burung puyuh tidak berbeda nyata sehingga menghasilkan bobot hidup yang tidak berbeda, artinya pertumbuhan yang cepat tetapi memiliki pola pertumbuhan yang sama sehingga proporsi komponen-komponen tubuhnya sama. Rahmawati (2013), menyatakan bahwa pemberian tepung daun pepaya melebihi $15 \%$ dapat meningkatkan bobot badan.

\section{Pengaruh Perlakuan Terhadap Bobot Karkas Burung Puyuh (gr)}

Karkas merupakan berat tubuh ternak potong setelah pemotongan dikurangi kepala, darah serta organ internal yaitu kaki dan bulu (Soeparno, 1994).Karkas burung puyuh adalah daging bersama tulang setelah dipisahkan dari kepala sampai batas pangkal leher, dari kaki sampai lutut serta isi rongga perut (Sugiharto, 2005). Bobot karkas (gr/ekor) diperoleh dengan cara menimbang karkas diakhir penelitian.

Tabel 6. Nilai rataan bobot karkas burung puyuh untuk masing-masing perlakuan (gram)

\begin{tabular}{|c|c|c|c|c|c|c|}
\hline \multirow{2}{*}{ Ulangan } & \multicolumn{4}{|c|}{ Perlakuan } & \multirow{2}{*}{ Total } & \multirow{2}{*}{ Rataan } \\
\hline & R0 & R1 & R2 & R3 & & \\
\hline 1 & 60,00 & 73,00 & 75,00 & 50,00 & 258,00 & 64,50 \\
\hline 2 & 36,00 & 58,00 & 71,00 & 70,00 & 235,00 & 58,75 \\
\hline 3 & 56,00 & 52,00 & 64,00 & 72,00 & 244,00 & 61,00 \\
\hline 4 & 70,00 & 52,00 & 54,00 & 68,00 & 244,00 & 61,00 \\
\hline
\end{tabular}




\begin{tabular}{lcccccc}
\hline 5 & 61,00 & 58,00 & 68,00 & 61,00 & 248,00 & 62,00 \\
6 & 59,00 & 51,00 & 33,00 & 64,00 & 207,00 & 51,75 \\
Total & 342,00 & 344,00 & 365,00 & 385,00 & 1436,00 & 359,00 \\
Rataan & 57,00 & 57,33 & 60,83 & 64,17 & 239,33 & 59,83 \\
\hline
\end{tabular}

Hasil penelitian pada Tabel 6, bahwa bobot karkas burung puyuh berkisar antara 33 gram sampai 75 gram, dengan rataan bobot karkas 59,83 gram. Bobot karkas rataan yang tertinggi ada pada perlakuan R3 ( ransum dengan penambahan tepung daun pepaya $15 \%$ ) dengan rataan bobot karkas 64,17 gram, sedangkan yang terendah ada pada perlakuan R0 (ransum tanpa penambahan tepung daun pepaya) dengan rataan bobot karkas 57,00 gram.

Untuk mengetahui pengaruh perlakuan terhadap bobot karkas tersebut dilakukan analisis sidik ragam pada Tabel 7 dibawah ini :

Tabel 7. Hasil analisis sidik ragam pengaruh perlakuan terhadap bobot karkas burung puyuh

\begin{tabular}{|c|c|c|c|c|c|c|}
\hline \multirow{2}{*}{ SK } & \multirow{2}{*}{$\mathrm{Db}$} & \multirow{2}{*}{$\mathrm{JK}$} & \multirow{2}{*}{$\mathrm{KT}$} & \multirow{2}{*}{$F_{\text {hit }}$} & \multicolumn{2}{|c|}{$\mathrm{F}$ tabel } \\
\hline & & & & & $\overline{0,05}$ & 0,01 \\
\hline Perlakuan & 3 & 204,3333 & 68,11111 & $0,54^{\text {tn }}$ & 3,1 & 4,94 \\
\hline Galat & 20 & 2491 & 124,55 & & & \\
\hline Total & 23 & 2695,333 & & & & \\
\hline
\end{tabular}

Keterangan : KK $=18,6531 \%$

$$
\text { tn = Tidak nyata }
$$

Hasil analisis sidik ragam Tabel 7 menunjukkan bahwa, bahwa pemberian tepung daun pepaya terhadap bobot karkas memberikan pengaruh yang tidak nyata $(\mathrm{P}>0,05)$, hal ini disebabkan karena konsumsi ransum dan kandungan protein ransum pada tiap perlakuan berbeda dengan pemberian tepung daun pepaya, sehingga pengaruhnya terhadap bobot karkas tidak terlalu tinggi.

\section{Pengaruh Perlakuan Terhadap Persentase Karkas Burung Puyuh}

Persentase karkas merupakan faktor yang penting untuk menilai produk dari ternak daging.Secara umum persentase karkas berkisar antara 65-75\% dari berat hidup (Priyanto, 1977).Faktor-faktor yang mempengaruhi persentase karkas adalah umur, perlemakan, bobot badan, jenis kelamin, kualitas dan kuantitas ransum (Soeparno, 1994). Berikut rataan persentase karkas burung puyuh pada masing-masing perlakuan dapat dilihat pada tabel di bawah ini : 
Tabel 8. Nilai rataan persentase karkas burung puyuh untuk masing-masing Perlakuan (\%)

\begin{tabular}{|c|c|c|c|c|c|c|}
\hline \multirow{2}{*}{ Ulangan } & \multicolumn{4}{|c|}{ Perlakuan } & \multirow{2}{*}{ Total } & \multirow{2}{*}{ Rataan } \\
\hline & R0 & $\mathrm{R} 1$ & R2 & R3 & & \\
\hline 1 & 68,18 & 73,73 & 75,75 & 64,10 & 281,76 & 70,44 \\
\hline 2 & 64,28 & 70,73 & 73,95 & 72,16 & 281,12 & 70,28 \\
\hline 3 & 68,29 & 68,42 & 69,56 & 69,23 & 275,5 & 68,88 \\
\hline 4 & 72,91 & 65,82 & 72,97 & 72,34 & 284,04 & 71,01 \\
\hline 5 & 70,93 & 69,87 & 70,10 & 65,59 & 276,49 & 69,12 \\
\hline 6 & 67,81 & 68,00 & 62,26 & 65,97 & 264,04 & 66,01 \\
\hline Total & 412,4 & 416,57 & 424,59 & 409,39 & 1662,95 & 415,74 \\
\hline Rataan & 68,73 & 69,43 & 70,77 & 68,23 & 277,16 & 69,29 \\
\hline
\end{tabular}

Hasil penelitian pada tabel, bahwa persentase karkas burung puyuh berkisar 62,26\% sampai $75,75 \%$ dengan nilai rataan persentase $69,29 \%$. Persentase rataan yang tertinggi ada pada perlakuan R2 (ransum dengan penambahan tepung daun pepaya sebanyak 10\%) dengan rataan bobot persentase $70,77 \%$, sedangkan yang terendah ada pada perlakuan R3 (ransum tanpa penambahan tepung daun pepaya) dengan rataan bobot persentase $68,23 \%$.

Untuk mengetahui pengaruh perlakuan terhadap persentase karkas tersebut dilakukan analisis sidik ragam pada tabel dibawah ini :

Tabel 9. Hasil analisis sidik ragam pengaruh perlakuan terhadap persentase karkas burung puyuh (\%)

\begin{tabular}{|c|c|c|c|c|c|c|}
\hline \multirow{2}{*}{ SK } & \multirow{2}{*}{$\mathrm{Db}$} & \multirow{2}{*}{ JK } & \multirow{2}{*}{$\mathrm{KT}$} & \multirow{2}{*}{$F_{\text {hit }}$} & \multicolumn{2}{|c|}{ F table } \\
\hline & & & & & 0,05 & 0,01 \\
\hline Perlakuan & 3 & 21,74825 & 7,249415 & $0,56^{\mathrm{tn}}$ & 3,1 & 4,94 \\
\hline Galat & 20 & 256,4848 & 12,82424 & & & \\
\hline Total & 23 & 278,2331 & & & & \\
\hline
\end{tabular}

Keterangan : $\mathrm{KK}=5,1682 \%$

$$
\text { tn = Tidak nyata }
$$

Hasil penelitian menunjukkan bahwa pemberian tepung daun pepaya memberikan pengaruh yang tidak nyata $(\mathrm{P}>0,05)$ terhadap persentase karkas pada burung puyuh.

\section{Pengaruh Perlakuan Terhadap Panjang Usus Burung Puyuh}

Sebagian besar pencernaan terjadi dalam usus halus, kemudian dilanjutkan ke ceca (usus buntu), usus besar dan kloaka.Usus halus pada ternak merupakan organ penting dalam pencernaan yang berfungsi untuk mengabsorsi nutrisi bahan pakan (Gillepsie, 2004).

Tabel 10. Nilai rataan panjang usus burung puyuh untuk masing-masing perlakuan (cm)

\begin{tabular}{|c|c|c|c|c|c|c|}
\hline \multirow{2}{*}{ Ulangan } & \multicolumn{4}{|c|}{ Perlakuan } & \multirow{2}{*}{ Total } & \multirow{2}{*}{ Rataan } \\
\hline & R0 & $\mathrm{R} 1$ & R2 & R3 & & \\
\hline 1 & 20,22 & 14,39 & 15,25 & 16,91 & 66,77 & 16,69 \\
\hline
\end{tabular}




\begin{tabular}{ccccccc}
\hline 2 & 12,42 & 13,47 & 18,67 & 16,73 & 61,29 & 15,32 \\
3 & 17,01 & 15,02 & 15,82 & 19,57 & 67,42 & 16,86 \\
4 & 14,05 & 17,22 & 14,90 & 14,71 & 60,88 & 15,22 \\
5 & 21,18 & 14,75 & 17,48 & 21,88 & 75,29 & 18,82 \\
6 & 13,09 & 17,91 & 15,90 & 14,22 & 61,12 & 15,28 \\
Total & 97,97 & 92,76 & 98,02 & 104,02 & 392,77 & 98,19 \\
Rataan & 16,33 & 15,46 & 16,34 & 17,34 & 65,46 & 16,37 \\
\hline
\end{tabular}

Hasil penelitian pada tabel bahwa panjang usus burung puyuh berkisar antara 12,42 cm sampai $21,88 \mathrm{~cm}$, dengan rataan panjang usus $16,37 \mathrm{~cm}$, rataan panjang usus yang tertinggi ada pada perlakuan R3 (ransum dengan penambahan tepung daun pepaya sebanyak $15 \%$ ) dengan rataan panjang usus $17,34 \mathrm{~cm}$, sedangkan yang terendah ada pada perlakuan R1 (ransum dengan penambahan tepung daun pepaya sebanyak 5\%) dengan rataan panjang usus $15,46 \mathrm{~cm}$.

Untuk mengetahui pengaruh perlakuan terhadap panjang usus tersebut dilakukan analisis sidik ragam pada Tabel 11

Tabel 11. Hasil analisis sidik ragam pengaruh perlakuan terhadap panjang Usus burung puyuh

\begin{tabular}{|c|c|c|c|c|c|c|}
\hline \multirow{2}{*}{ SK } & \multirow{2}{*}{$\mathrm{Db}$} & \multirow{2}{*}{ JK } & \multirow{2}{*}{ KT } & \multirow{2}{*}{$F_{\text {hit }}$} & \multicolumn{2}{|c|}{$\mathrm{F}_{\text {tabel }}$} \\
\hline & & & & & 0,05 & 0,01 \\
\hline Perlakuan & 3 & 10,59185 & 3,530615 & $0,51^{\mathrm{tn}}$ & 3,1 & 4,94 \\
\hline Galat & 20 & 138,2508 & 6,912538 & & & \\
\hline Total & 23 & 148,8426 & & & & \\
\hline
\end{tabular}

Keterangan: $\mathrm{KK}=16,0609 \%$

$\mathrm{tn}=$ Tidak nyata

Hasil analisis sidik ragam pada Tabel 11 menunjukkan bahwa, pembelian tepung daun pepaya terhadap panjang usus memberikan pengaruh yang tidak nyata $(\mathrm{P}>0,05)$ terhadap panjang usus.

\section{Rekapitulasi Hasil Penelitian}

Dari hasil penelititan ini, maka dapat dibuat rekapitulasi data yang dapat dilihat pada Tabel 12.

Tabel 12. Rekapitulasi Penelitian

\begin{tabular}{ccccc}
\hline \multirow{2}{*}{ Perlakuan } & \multicolumn{4}{c}{ Parameter } \\
\cline { 2 - 5 } & $\begin{array}{c}\text { Bobot Hidup } \\
(\text { gram })\end{array}$ & $\begin{array}{c}\text { Bobot Karkas } \\
(\text { gram })\end{array}$ & $\begin{array}{c}\text { Persentasekarkas } \\
(\%)\end{array}$ & $\begin{array}{c}\text { Panjang Usus } \\
(\mathrm{cm})\end{array}$ \\
\hline R0 & $82,50^{\text {tn }}$ & $57,00^{\text {tn }}$ & $68,73^{\text {tn }}$ & $47,83^{\text {tn }}$ \\
R1 & $82,33^{\text {tn }}$ & $57,33^{\text {tn }}$ & $69,43^{\text {tn }}$ & $46,00^{\text {tn }}$ \\
R2 & $85,17^{\text {tn }}$ & $60,83^{\text {tn }}$ & $70,77^{\text {tn }}$ & $42,83^{\text {tn }}$ \\
R3 & $93,83^{\text {tn }}$ & $64,17^{\text {tn }}$ & $68,23^{\text {tn }}$ & $46,00^{\text {tn }}$ \\
\hline
\end{tabular}


Berdasarkan Tabel 12, rekapitulasi diatas terlihat bahwa pemberian tepung daun pepaya (Carica papaya) dalam ransum burung puyuh memberikan pengaruh yang tidak nyata ( $\mathrm{P}>0,05)$, terhadap bobot hidup, bobot karkas, persentase karkas, dan panjang usus.

\section{KESIMPULAN}

Dari hasil penelitian dapat disimpulkan, bahwa pemberian tepung daun pepaya (Carica papaya) dalam ransum tidak berpengaruh pada bobot hidup, bobot karkas, persentase karkas dan panjang usus burung puyuh. Perlakuan terbaik dari penelitian yang dilakukan terdapat pada ransum dengan penambahan tepung daun pepaya $10 \%$ terhadap persentase karkas sebesar 70,77\%.

\section{DAFTAR PUSTAKA}

Anggorodi, 1995.Nutrisi Aneka Ternak Unggas. PT Gramedia Pustaka Utama, Jakarta

Appleby, et al 1992.Poultry production System.CAB Internasional. Wallingfort, Oxon.

Bidura, Candrawati dan Sumardani, 2007.Pengaruh Penggunaan Daun Katuk (Sauropus Androgynus) Dalam Ransum Terhadap Penampilan Ayam Broiler. Penerba Swadaya, Jakarta.

Departemen Kesehatan RI, 1979. Daftar Komposisi Bahan Makanan, Bharata. Jakarta.

Elly dan Kinanti. 1992. Puyuh Tata Laksana Budi Secara Komersial. Penerba Swadaya. Jakarta.

Gillespie, R.J. 2004.Moderen Livesock And Poultry Produksien. 7 Edition. INC.

Thomson Learning. United States.

Hardjosubroto, W. Dan J. M. Astuti.1993. Buku Pintar Peternakan. Jakarta. PT Gramedia Widiasarana Indonesia.

Irwanto, 2005.Perkembangan Burung Puyuh. Penebar Swadaya. Jakarta.

Jull, M.A. 1977. Poultry Husbandry 3rd. Mc Grow Hill Book Company, Ney York

Karoglu, M and Durdag, H. 2005. The Influence Of Dietary Probiotic (Saccharomyces Cerevisiae) Suplementation And Differend Slaughter Age On The Performance, Slaugther And Carcass Properties Of Broiler. International Journal Of Poulltry Science, Vol. 5, N. 4, 309-316

Listiyowati, E. Dan K. Roospitasari, 2000. Tatalaksana Budidaya Puyuh Secara Komarsial. Edisi Revisi. Penebar Swadaya, Jakarta 